\title{
A study to Assess the Impact of warm water foot immersion therapy on regulation of body temperature among patients with fever.
}

Ms.Ezhilarasi.E, **Dr.Renuka.K \& ***Ms.Ponmani.C

\section{Abstract:}

Objective- To evaluate the effectiveness of warm water foot immersion therapy on regulation of normal body temperature among patients with fever. Method- Quantitative research approach, Experimental design and, Simple Random Sampling Technique where adopted for this study. Result - There was a reduction in mean body temperature of about $1.1^{\circ} \mathrm{F}$ after application of warm water foot immersion therapy among patients with fever. For the best of our knowledge this therapy could be used as an alternative method to treat fever and this could be a cost effective without any side effects. Conclusion-This study concluded that warm water foot immersion therapy is a non-pharmacological and complementary therapy to manage the body temperature within the normal range.

\section{Keywords: Warm Water Foot Immersion Therapy, Fever, Impact}

\section{INTRODUCTION}

Fever is a natural response of our body to any infectious or non-infectious disease by increasing temperature regulatory set point ${ }^{3}$. Several studies have been reported that fever can be treated naturally without any side effects by various therapies like warm water therapy, cold water therapy or alternating the both. In this study warm water foot, immersion therapy has been chosen. Warm water foot therapy stimulates the immune response, removes the toxin, relieves the congestion in the body, and there by reduces the fever. It dilates the blood vessels and cools the body. It also relieves fever-associated symptoms like body pain, head ache, fatigue, insomnia and increase the comfort level of the patient. ${ }^{6}$

\section{OBJECTIVES}

- To assess the pretest level of body temperature among patients with fever in experimental and control group.

- To evaluate the effectiveness of warm water foot immersion therapy on regulation of normal body temperature among patients with fever in experimental group.

- To associate the post test level of body temperature with selected demographic variable among patients with fever in experimental group.

\section{METHODOLOGY:}

Quantitative research approach was applied for the study. Experimental design was used for this study. The study was conducted at MGMCRI, Puducherry. The target population of the study included, Patient with fever (Body temperature ranges from $99^{\circ} \mathrm{F}$ to $103^{\circ} \mathrm{F}$ ), 60 samples were selected by Simple random sampling technique. 


\section{Inclusion criteria:}

- Patients with body temperature ranging between $99^{\circ} \mathrm{F}-103^{\circ} \mathrm{F}$.

- Age between $20-60$ years.

- Patients with fever due to medical illness or minor ailments.

- Patient who could tolerate warm water.

\section{Exclusion criteria:}

- Patients with rigor \& patients who were critically ill.

- Patients with foot ulcer or wound in the foot.

- Patients with peripheral vascular diseases like Burger's disease, varicose vein, DVT etc.

- Unconscious patients.

- Patient who were bed ridden

\section{Data collection instrument and Technique:}

The Tool consisted of 2 parts

PART -1 It consisted of interview schedule to assess the demographic data such as Age, gender, religion, residential area, educational status, type of work, occupational status, family income ,unhealthy habits, dietary pattern, health access during illness, characteristics of the fever, fever associated symptoms, reason for infection, reason for fever, range of temperature, general measures adopted during fever.

\section{Data collection instrument and Technique:}

The Tool consisted of 2 parts

PART -1 It consisted of interview schedule to assess the demographic data such as Age, gender, religion, residential area, educational status, type of work, occupational status, family income ,unhealthy habits, dietary pattern, health access during illness, characteristics of the fever, fever associated symptoms, reason for infection, reason for fever, range of temperature, general measures adopted during fever.

\section{Level of fever}

Fever can be categorized into

\begin{tabular}{|c|c|}
\hline $\begin{array}{c}\text { Level of } \\
\text { temperature }\end{array}$ & Category \\
\hline Below $99^{\circ} \mathrm{F}$ & Normal \\
$99^{\circ} \mathrm{F}-100^{\circ} \mathrm{F}$ & Low pyrexia \\
$100^{\circ} \mathrm{F}-103^{\circ} \mathrm{F}$ & Moderate pyrexia \\
$103^{\circ} \mathrm{F}-105^{\circ} \mathrm{F}$ & High pyrexia \\
$105^{\circ} \mathrm{F}$ and over & Hyper pyrexia \\
\hline
\end{tabular}

The result revealed that out of 30 subjects in experimental group 10(33.3\%) had low pyrexia and 20(66.7\%) had moderate pyrexia. After the intervention (i.e.) Warm Water Foot Immersion Therapy11 (36.7\%) patient got relieved from fever, $17(56.7 \%)$ had low pyrexia and only 2 had moderate pyrexia. But in control group out of 30 samples, 16(53.3\%) had low pyrexia and $14(46.7 \%)$ had moderate pyrexia in pre test. The posttest value revealed that $14(46.7 \%)$ had low pyrexia and $16(53.3 \%)$ had moderate pyrexia. These shows with warm water foot immersion therapy, the temperature got reduced and in the control group remained the same.

Table 1: Distribution of pre-test data on Mean Body Temperature among patients with fever in experimental and control group. 


\begin{tabular}{|c|c|c|c|c|c|c|}
\hline & & & & & \multicolumn{2}{|c|}{$N=60$} \\
\hline Group & $\begin{array}{c}\text { Mean body } \\
\text { temperature } \\
\left({ }^{\circ} \mathrm{F}\right)\end{array}$ & $\begin{array}{c}\text { Mean } \\
\text { Difference }\end{array}$ & $N$ & $S D$ & $\begin{array}{c}\text { 't' } \\
\text { value } \\
\text { (df) }\end{array}$ & Pvalue \\
\hline $\begin{array}{c}\text { Experimental } \\
\text { Group }\end{array}$ & 99.127 & \multirow[t]{2}{*}{-0.813} & 30 & 0.5343 & \multirow{2}{*}{$\begin{array}{c}- \\
5.175 \\
(58)\end{array}$} & \multirow{2}{*}{$\begin{array}{c}0.000^{* * * *} \\
\mathrm{HS}\end{array}$} \\
\hline Control Group & 99.94 & & 30 & 0.675 & & \\
\hline
\end{tabular}

${ }^{* * *} \mathrm{HS}$ - Highly significant at $\mathrm{p}<0.001$

Table 1 show the comparison of pre test values of mean body temperature of patients with fever in two groups. The data reveal that the mean difference was only 0.28 and the ' $\mathrm{t}$ ' value is 1.67 which is not significant at $\mathrm{p}<0.05$. This data concludes that there is no significant difference between the pre-test values of experimental and control group. It infers that all subjects were having different levels of fever irrespective of group they belong to. The above table further denotes that patients in experimental group had increased mean body temperature than patients in control group.

Table 2: Comparison of post test data of mean body temperature between patients with fever in experimental and control group.

\begin{tabular}{|c|c|c|c|c|c|c|}
\hline & & & & & \multicolumn{2}{|c|}{$N=60$} \\
\hline Group & $\begin{array}{c}\text { Mean body } \\
\text { temperature } \\
\left({ }^{\circ} \text { F }\right)\end{array}$ & $\begin{array}{c}\text { Mean } \\
\text { Difference }\end{array}$ & $N$ & $S D$ & $\begin{array}{c}\text { 't' } \\
\text { value } \\
\text { (df) }\end{array}$ & Pvalue \\
\hline $\begin{array}{c}\text { Experimental } \\
\text { Group }\end{array}$ & 99.127 & \multirow{2}{*}{-0.813} & 30 & 0.5343 & \multirow{2}{*}{$\begin{array}{c}- \\
5.175 \\
(58)\end{array}$} & \multirow{2}{*}{$\begin{array}{c}0.000^{* * *} \\
\mathrm{HS}\end{array}$} \\
\hline Control Group & 99.94 & & 30 & 0.675 & & \\
\hline
\end{tabular}

${ }^{* * *} H S$ - Highly significant at $p<0.001$

Table: 2 show the comparison of posttest values of two groups. The data reveal that the mean difference and the ' $t$ ' value was -0.813 and -5.175 respectively, which is significant at $\mathrm{p}<0.05$. This data concludes that there was significant difference between the post-test values of experimental and control group.

\section{Major findings}

$>$ In regard to effectiveness of warm water foot immersion therapy on thermoregulation among subjects in experimental group, the obtained value was $0.000^{* * *}$ which was highly significant at $\mathrm{p}<0.001$ level. There was reduction in mean body temperature of $1.1^{\circ} \mathrm{F}$. Hence the null hypothesis $\left(\mathrm{H}_{0} 1\right)$ was accepted which shows its effectiveness.

$>$ It infers that the mean pre test body temperature in control group was $99.9^{\circ} \mathrm{F}$ and post test was $99.94^{\circ} \mathrm{F}$. The obtained paired $t^{\prime}$ value was -0.902 and $\mathrm{p}$ value was 0.375 which not significant at $\mathrm{p}<0.05$ level. It was inferred that there was no reduction in body temperature among control group. 


\section{DISCUSSION:}

The first objective of the present study was to assess the existing level of body temperature and categorize the level of fever among patients with fever in experimental and control group during the pre-test.

The present study results showed that the comparison of pre test values of two groups, the data reveals that the mean difference was only 0.28 and the ' $t$ ' value is 1.67 which is not significant at $\mathrm{p}<0.05$. This data concludes that there is no significant difference between the pre-test values of experimental and control group

The second objective was to evaluate the effectiveness of warm water foot immersion therapy among patients with fever in experimental group during the post test.

In the present study showed that the mean, standard deviation, paired ' $t$ ' value of patients with fever in experimental group. It reveals that, the mean pre test body temperature score was $100.2^{\circ} \mathrm{F}$ and mean post body temperature score was $99.1{ }^{\circ} \mathrm{F}$ and $\mathrm{p}$ value was $0.000^{* * *}$. It was highly significant at $\mathrm{p}<0.001$ level. There is a significant difference between pre-test and post-test values of body temperature in experimental group. It was inferred that Warm Water Foot Immersion Therapy was highly effective in reduction of Body Temperature among patient with fever.

\section{CONCLUSION}

The study proved the fact that, there was a reduction in mean body temperature of about $1.1^{\circ} \mathrm{F}$ after application of warm water foot immersion therapy among patients with fever. For the best of our knowledge this therapy could be used as an alternative method to treat fever and this could be cost effective without any side effects.

\section{REFERENCE}

1. Alan $\mathrm{K}$ Done. Treatment of fever in 1982: A Review. The American Journal of Medicine. 1983 June: 27-3

2. Barie PS. Guidelines for evaluation of new fever in critically ill adult patients. American College of Critical Care Medicine and the Infectious Diseases Society of America. Apr 2008;36(4):1330-49.

3. Blumenthal. Fever, concepts old and new. Journal of the Royal society of Medicine. 1997 July; Vol 90: 391 - 394

4. Burns SB et al. Alternative Complement Medicine. 1997;3:105-107.

5. Fathia Attia Mohammed. A comparison of vinegar compress versus cold water and water with vinegar for treating of fever at tropical hospitals. International journal of nursing science. 2012;2(4):38 -36

6. Harmer $A R$ et al. Land-based versus water-based rehabilitation following total knee replacement. Feb 2009; 61(2):184-191.

7. Henker R. Fever: applying research to bedside practice. AACN. Jan 2007;18(1):76-87.

8. Janice E. Sullivan. Clinical report fever and antipyretic use in children. American academy of pediatrics.2011;127 (3):580-84

9. Judith ' $O$ ' et al. Use and effectiveness of hypothermia blankets for febrile patients in the ICU. Clinical Infectious Disease. 1997 June: 1208-1213.

10. Selvakumari R.. Hot Water Foot Bath Therapy for patient with fever. Nightingale Nursing Times. 2011 March; 6(1) 